Ethiopian Journal of Environmental Studies \& Management 8(2): 161 - 170, 2015.

ISSN:1998-0507

doi: http://dx.doi.org/10.4314/ejesm.v8i2.6

Submitted: November 18, 2014

Accepted: February 9, 2015

\title{
ASSESSING THE CHALLENGES OF ACCESS TO HOUSING FINANCE IN THE NORTH CENTRAL STATES OF NIGERIA
}

\author{
KUMA, S.S. \\ Department of Estate Management and Valuation, Federal University of Technology, PMB. \\ 65, Minna Niger State, Nigeria. Email: kumass@futminna.edu.ng
}

\begin{abstract}
This paper assesses those challenges that impede effective access to housing finance in the North Central States of Nigeria. It assesses the availability and distribution of primary mortgage structures within the study area, to examine the affordability of mortgage loans, the predominant sources of housing finance as well as analysis of the factors identified. Data were collected through the use of questionnaire and certified secondary sources for analysis. The result revealed that, there is inadequate availability of primary mortgage institutions. Four mortgage institutions were available in the six states of the north central region of Nigeria and loans provided are not easily affordable. This has pushed most prospective homeowners to rely on savings from income and borrowing from cooperative societies. However, due to the insufficiency of funds from these sources, houses are developed on incremental basis often taking an average of between 6 and 10 years to complete. In consideration of the result from Kendall's coefficient of concordance, the paper concludes that, high interest rates, land titles and absence of primary mortgage institutions are the top most significant factors impeding effective access to housing finance within the North Central States of Nigeria.
\end{abstract}

Key Words: Housing finance, sources, accessibility, challenges.

\section{Introduction}

Finance is an essential requirement for housing development and has been variously adjudged to be the lifeline in real estate development. Tibaijuka (2002) opined that, the availability of adequate housing finance is the corner stone of any effective and sustainable shelter project, while Akinmoladun and Oluwoye (2007) noted that the inadequate quality and quantity of housing in the developing world and particularly in Nigeria, is largely due to poor and ineffective access to finance.

However, in spite of the significance of effective access to housing finance, it is becoming increasingly challenging for prospective homeowners to access it particularly in developing economies. In most cases where homeownership top household's scale of preference, they often forgo expenditures on other domestic consumptions to meet their desired goal. In Nigeria presently, $60 \%$ of the new houses developed each year are financed through personal income and savings and sometimes with the assistance from local cooperative societies (National Bureau of Statistics NBS, 2012). A report from the Living Standard Measurement Survey (LSMS) by NBS in 2012 revealed that, 
only $38 \%$ of households' have formal bank accounts in the North Central Nigeria which equals the percentage of the overall national average and only $4 \%$ use formal credit in the development of their homes. These formal credits include those from Deposit Money Banks (DMBs), Micro Finance Institutions (MFIs) and Primary Mortgage Institutions (PMIs). The situation here presents an indication that the formal financial institutions are the least source of credit to prospective home developers. Some empirical evidence in some case studies indicates that, stringent and cumbersome lending policies of these formal finance institutions have influenced borrowers' choice of finance and as well shifted their preferences to other informal sources of housing finance (Ojo, 2005; Ndibe and Kuma, 2010). The nature of some of the credit policies have also pegged at both ends categories of developers with their associated challenges. For instance, developers in the formal private sector on one hand are financed mainly through DMBs at very high interest rates with other rigid lending conditions consequently making their housing stock quite expensive. Whereas the low income home builders on the other hand, seek for funds from informal sources such as, thrift societies, Local money lenders and other informal financial arrangements to meet their targets (Tomlinson, 2007). However, developments financed through these sources are carried out on incremental basis taking several years to complete.

The above backdrop has thus given rise to this study which aims at assessing the impediments to housing finance accessibility in the North Central States of Nigeria. The study basically assess the availability of primary mortgage structures in the region, the affordability of loans, the predominant sources of housing finance and challenges therewith.

\section{Challenges of Access to Housing Finance}

Some empirical studies relating to the problems confronting accessibility to housing finance particularly in Nigeria have revealed similar outcomes that revolve around, income/wage levels and lending policies of formal financial (mortgage) institutions. For instance, Dung-Gwom and Mallo (2011) appraises the challenges confronting access to credit facilities for home acquisition in Plateau State of Nigeria with emphasis on the low income earners. The study test for eligibility of households for credit facilities and examined other lending requirements. The outcome indicates income levels and lending requirements possess the most challenge to households' access to credits. Anayochukwu (2011) came under similar findings while examining the problems and prospects of financing urban housing in the South Eastern States of Nigeria. The result also shows that income and lending requirements have accounted for only $11 \%$ of homeowners who accessed mortgage loans for the development of their houses. Whereas in the South Western States, the study of Ojo and Ighalo (2008) found that households are impaired mainly by lending requirements like eligibility criterion, statutory land titles and high interest rates which also influences their choice of housing loan packages based on their ability to access and willingness to repay.

Kabir and Ikem (2013) provided a dual approach in their investigation into the availability of funds for private real estate developers in Abuja, Nigeria. First, it assesses the factors weighing against availability of funds and second, the constraints to accessing the available funds. Findings provided evidence that high cost of funds, cost of construction and difficulties in obtaining statutory land titles are the 3 most significant factors impeding on effective access to housing finance. 
While the study also provides information on the sources of housing finance, it centres on the formal private developers who basically develop for investment purposes rather than owner-occupier developments. Since evidence of variation exists in the challenges affecting these different categories of developers following financial options available to these them also vary (Tomlinson, 2007).

The above literature have lay impetus to this study which will not only assess the challenges to housing finance accessibility but also its effect on duration of housing development and also provide a comparative approach to a wider case study where similar studies are unavailable.

\section{Research Methodology}

Data for the study were collected through primary and certified secondary sources. 1,600 questionnaires were designed and distributed to those households (land owners) who have developed their homes and those who are still developing selected through a purposive sampling. The questionnaires were distributed in the ratio of 400/State in the 4 selected states; (Benue, Kogi, Nasarawa and Niger). A total of 1,342 were filled and returned representing $83.7 \%$ response rate of the survey. See figure 1 below showing the selected states in the North Central Nigeria.

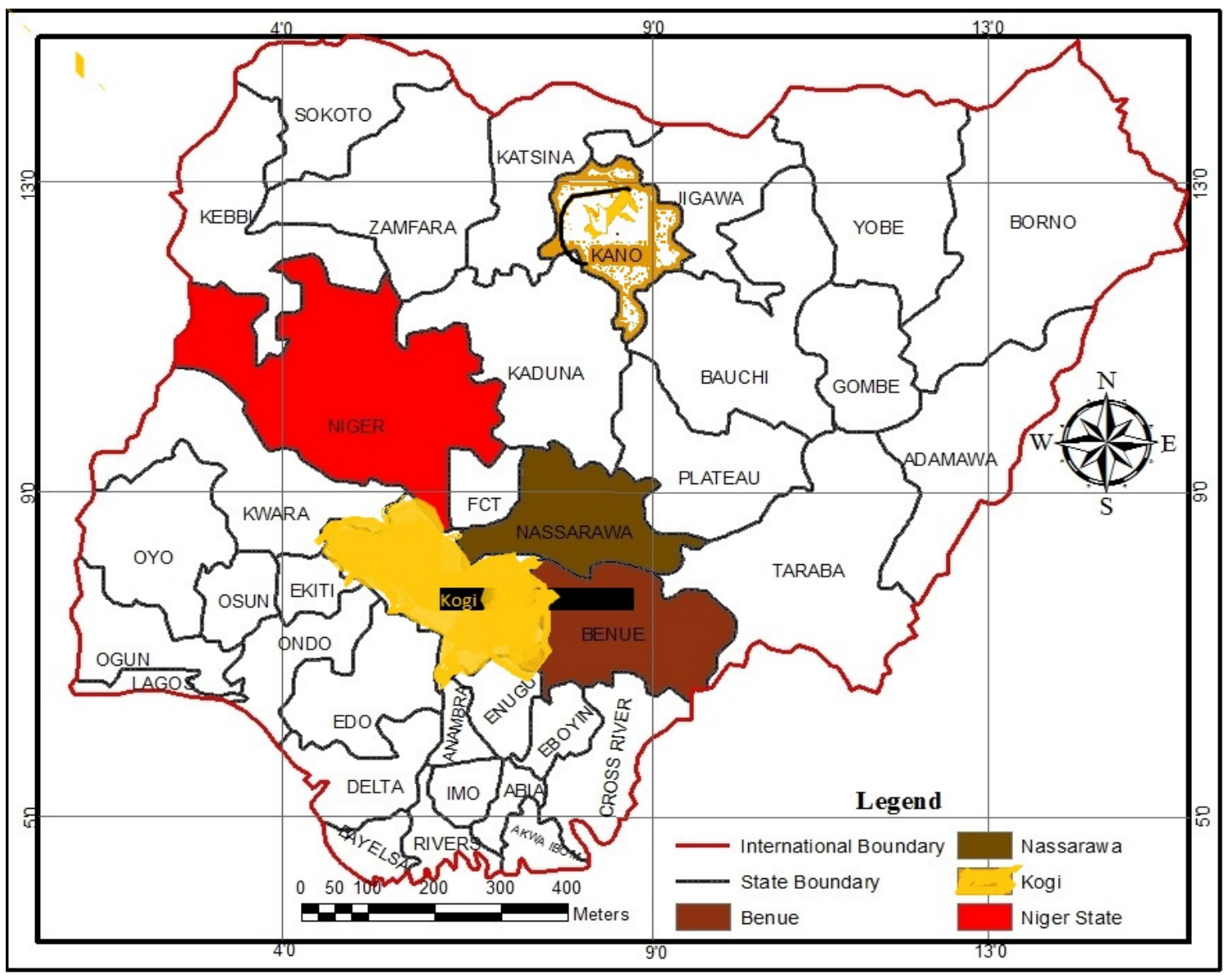

Source: Google Maps, 2013

Figure 1.The selected States in the North Central Nigeria 
The secondary sources of data are from National Bureau of Statistics NBS, Central Bank of Nigeria CBN and the Federal Mortgage Bank of Nigeria FMBN.

Analysis of data was made using descriptive methods and ANOVA Single factor technique. Respondents were also given an array of factors affecting access to housing finance to select as applicable to them and weigh on a 3-point scale indicating $\mathbf{1}=$ Less significant, $\mathbf{2}=$ Significant and $\mathbf{3}=$ Highly significant. The factors are then ranked in order of significance following their mean values. The Kendall's Coefficient of Concordance (W) was used to determine the relationship among the pairs of rankings in the 4 cities studied and is executed by;

$W=\left[12 \sum J_{1}^{2}-3 k^{2} n(n+1)^{2}\right] /\left[k^{2} n\left(n^{2}-1\right)\right.$ Where $T_{1}^{2}$ is the squared sum of ranks for each of the $n$ factors, while $n$ is the number of factors being ranked; and $k$ is the number of towns from which the ranking of the factors were taken. The coefficient ranges from $\mathbf{0}$ (complete disassociation) to $\mathbf{1}$ (complete or perfect association). The expected outcome here provides statistical evidence for the generalisation of findings in the study area.

\section{Results and Discussion}

Availability and Distribution of Primary Mortgage Institutions (PMIs)

The number of PMIs in Nigeria has continued to fluctuate with an uneven distribution in the regions of the country. Statistical evidence as illustrated in Figure 2 below shows that, a total of 85 registered PMIs were available and doing financial businesses in the country as at June, 2014. ) However, the annual trend in the number of PMIs witnessed a significant drop of about $59.3 \%$ between year 2000 and 2001, and $22.8 \%$ in 2010 respectively.

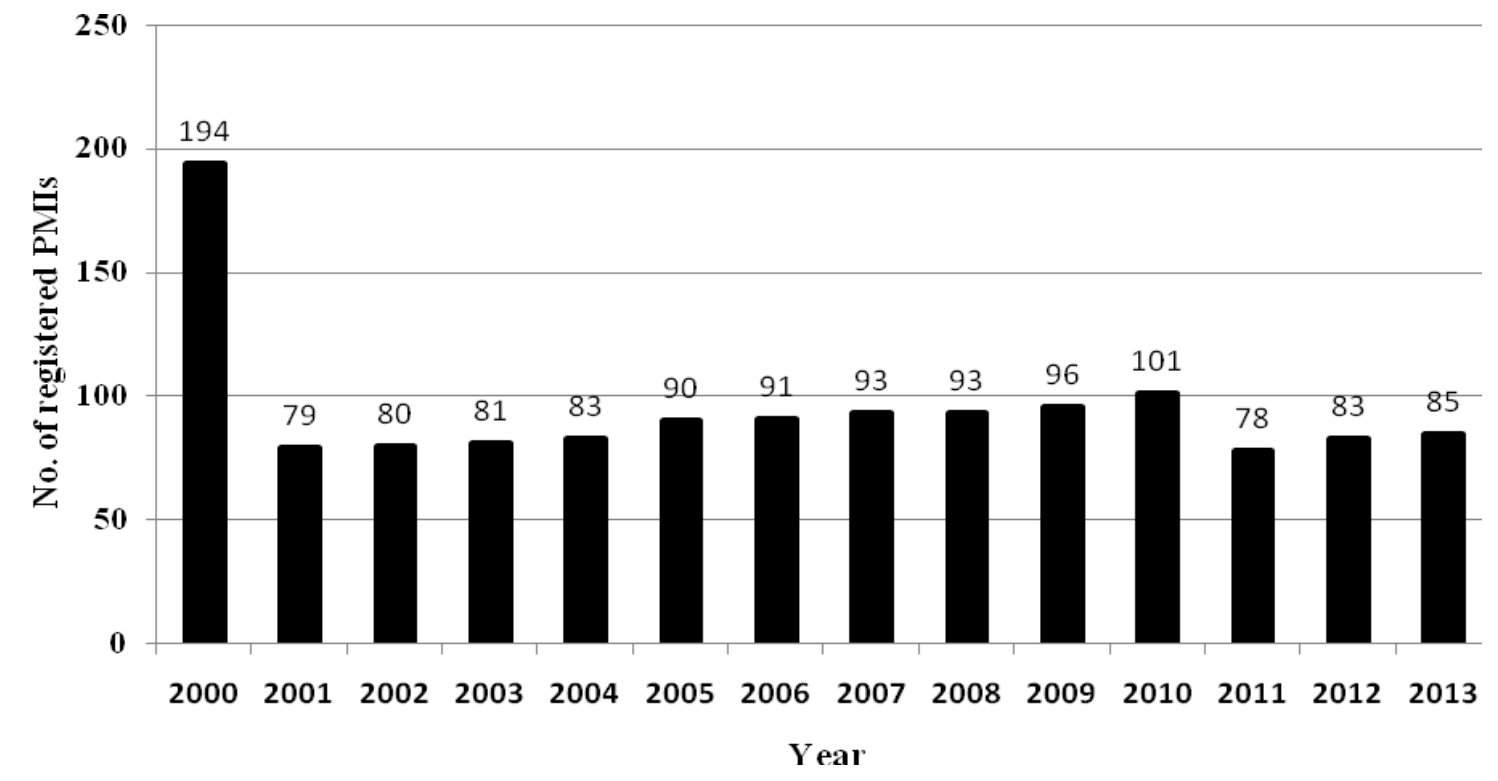

Source: Compiled from Central Bank of Nigeria (CBN, 2013)

Figure 2: Annual trend in the number of registered PMIs in Nigeria (2000-2013)

The geographical distribution of the PMIs across the regions of the country has shown an uneven pattern. The South-Western Region has the highest concentration of PMIs with $62.35 \%$ of the National total as at December, 2013. This is followed by South-South with $7.06 \%$ and the least being the North (NE, NW and NC) with $4.71 \%$ each. 
Table 1: Regional distribution of registered PMIs in Nigeria

\begin{tabular}{llll}
\hline Region & No. of States & No. of PMIs & $\begin{array}{l}\text { Percentage of } \\
\text { total }\end{array}$ \\
\hline North East (NE) & 6 & 4 & 4.71 \\
North West (NW) & 7 & 4 & 4.71 \\
North Central (NC) & $\mathbf{6}$ & $\mathbf{4}$ & $\mathbf{4 . 7 1}$ \\
South East (SE) & 5 & 5 & 5.88 \\
South West (SW) & 6 & 53 & 62.35 \\
South South (SS) & 6 & 6 & 7.06 \\
$*$ The FCT (Abuja) & - & 9 & 10.59 \\
Total & 36 & 85 & 100 \\
\hline
\end{tabular}

Source: Compiled from CBN, 2013. *Federal Capital Territory (Abuja)

The NC region has only 4 registered and operating PMIs and comprised of 6 states. However, 2 of the PMIs have been registered and licensed before the year 2000, the remaining 2 are in their $4^{\text {th }}$ and $8^{\text {th }}$ years of operation respectively. The implication here is that, $50 \%$ of the available PMIs are relatively new in the financial market and will not have generate enough capital base to meet up with the increasing level of housing finance needs of prospective homeowners.

Income Profile and Affordability of Mortgage Loans

Table 2: Mean distribution of respondents on monthly income profile

\begin{tabular}{llll}
\hline Income Range $(100)$ & $\mathrm{N}$ & Mean & SD \\
\hline $10-30$ & 151 & 37.75 & 4.787 \\
$30.1-45$ & 162 & 40.50 & 7.047 \\
$45.1-65$ & 207 & 51.75 & 9.535 \\
$65.1-85$ & 204 & 51.00 & 12.138 \\
$85.1-105$ & 195 & 48.75 & 9.323 \\
$105.1-125$ & 140 & 35.00 & 6.481 \\
$125.1-145$ & 110 & 27.50 & 8.185 \\
$145.1-165$ & 91 & 22.75 & 5.909 \\
$165.1 \&$ above & 82 & 20.50 & 7.047 \\
\hline
\end{tabular}

Table 2 above shows the monthly income group of the respondents from the various occupational sectors in the study area. This shows that a higher mean of 51.17 for respondents who earned between $\$ 45,100$ - $\$ 65,000$ (\$289.59 - \$417.36). This is closely followed by a mean value of 51.00 for those between $\$ 65,100$ - $\$ 85,000$ (\$418.0 - \$545.78) income groups. In order to test for the level of finance affordability using income and mortgage repayment, Table 3 below shows the mortgage variable used in the computation of the amortisation schedule.

Table 3: Mortgage variables

\begin{tabular}{llll}
\hline Item & Rate $(\%)$ & $\begin{array}{l}\text { Amount } \\
\text { (N'million) }\end{array}$ & $\begin{array}{l}\text { Dollar } \\
\text { Equivalent }\end{array}$ \\
\hline Average housing price & - & 4.20 & $26,968.02$ \\
Equity Financing & 10 & 0.42 & $2,696.80$ \\
Loan Amount & 90 & 3.78 & $24,271.22$ \\
Mortgage Interest Rate & 6 & - & \\
\hline
\end{tabular}

Note: US \$1 = 155.74 
Using the mortgage multiplier index (MMI),

$$
\text { MMI }=\left[(t / m) /\left(1-\left(1 /(1+l / m)^{n m}\right)\right)\right] \ldots \ldots \ldots \ldots \ldots \ldots \ldots . .1
$$

where, $\boldsymbol{i}$ is the mortgage interest rates, $\mathbf{n}=$ duration of loan which is considered here for 5,10 and 15 years respectively, and $\boldsymbol{m}=$ the number of compounding periods per year; hence for monthly mortgage repayment, the compounding periods is 12 (which represents 12 months in a calendar year).The loan amount $(\overline{\mathbf{a}})$ is then multiplied by MMI to give the monthly repayment (MRp);

$$
\operatorname{MRp}=\overline{\mathrm{a}} \times\left[(\mathrm{t} / m) /\left(1-\left(1 /(1+i / m)^{n m}\right)\right)\right] \ldots \ldots \ldots \ldots \ldots \ldots . .2
$$

With the loan amount of $\$ 3.78$ million, the monthly repayment will be $\$ 73,007.98$ for loan duration of 5 years, $\$ 41,965.75$ for 10 years and $\$ 31,897.79$ for 15 years respectively. Therefore, in measuring the ratio of income to monthly repayment, the income group of $\$ 19,700$ - $\$ 239,500$ will expend more than $30 \%$ of their monthly income hence not considered eligible (unaffordable) Table 4 below.

Table 4: Housing finance affordability

\begin{tabular}{llll}
\hline $\begin{array}{l}\text { Duration of Loan } \\
\text { (Years) }\end{array}$ & $*$ MRp ( $)$ & $\begin{array}{l}\text { Income } \\
\left(\mathrm{N}^{\prime} 000\right)\end{array}$ & Group \\
\hline 5 & $73,007.98$ & $\begin{array}{l}19.7-239.5 \\
240.0 \& \text { above }\end{array}$ & $\begin{array}{l}\text { Not Affordable } \\
\text { Affordable }\end{array}$ \\
& & $19.7-134.5$ & $\begin{array}{l}\text { Not affordable } \\
\text { Affordable }\end{array}$ \\
10 & $41,965.75$ & $135.0 \&$ above & Not affordable \\
& & $19.7-101.5$ & Affordable \\
\hline
\end{tabular}

*MRp $=$ Monthly Repayment

The duration of loan most times is considered on the basis of the mortgagor's years on his/her current employment particularly for those in the public sector because the more years in employment, the lesser years left before retirement hence, the lesser the duration of loan to be granted. Income is also considered on individual's account holder and not the total households' (both spouse) and or any other member of the household.

\section{Sources of Access to Housing Finance}

The data here indicates the various sources of housing finance available to households in the study area as 5 major sources were identified.

Table 5: Respondents' sources of access to housing finance

\begin{tabular}{lllllllll}
\hline Source of Finance & \multicolumn{3}{c}{ Makurdi } & \multicolumn{3}{c}{ Lokoja } & \multicolumn{3}{c}{ Lafia } & \multicolumn{3}{c}{ Minna } \\
\cline { 2 - 9 } & Freq & $\%$ & Freq & $\%$ & Freq & $\%$ & Freq & $\%$ \\
\hline Personal savings & 78 & 21.5 & 103 & 31.7 & 82 & 26.5 & 98 & 28.4 \\
Cooperative Society & 101 & 27.9 & 81 & 24.9 & 78 & 25.2 & 72 & 20.9 \\
Loan from PMIs & 39 & 10.8 & 11 & 3.4 & 3 & 1.0 & 12 & 3.5 \\
Loan from the DMBs & 31 & 8.6 & 9 & 2.8 & 15 & 4.8 & 17 & 4.9 \\
$\begin{array}{l}\text { Personal savings } \\
\text { Cooperative society }\end{array}$ & 113 & 31.2 & 121 & 37.2 & 132 & 42.6 & 146 & 42.3 \\
Total & 362 & 100 & 325 & 100 & 310 & 100 & 345 & 100 \\
\hline
\end{tabular}

DMBs = Deposit Money Banks (Commercial), PMIs = Primary Mortgage Institutions 
Personal savings and cooperative societies as indicated in Table 5 above are the predominant sources of finance. In Makurdi personal savings and cooperative societies contributes about $31.2 \%$ of total access by respondents. Lokoja 37.2\%, Lafia $42.6 \%$ while in Minna it contributes $42.3 \%$ of the total access by the sampled households. The PMIs is the least source contributing only $10.8 \%, 3.42 \%, 1.0 \%$ and $3.5 \%$ in Makurdi, Lokoja, Lafia and Minna respectively.

Table 6: Mean distribution and ranking of sources of housing finance

\begin{tabular}{llll}
\hline Sources of finance & N & Mean & Ranking \\
\hline Personal Savings & 361 & 90.3 & 2 \\
Cooperative Society & 332 & 83.0 & 3 \\
Loan from PMIs & 65 & 16.3 & 5 \\
Loan from the DMBs & 72 & 18.0 & 4 \\
Personal Savings and Cooperative Societies & 512 & 128.0 & 1 \\
\hline
\end{tabular}

Using the mean values to rank the sources of finance, the result indicates that majority of the households access finance for housing development through a combination of personal savings and cooperative societies, ranked 1 st with a mean value of 128.0. However, the least source is through the PMIs, ranked 5th with a mean value of 16.3. Further, a test of variance of the sources of finance among the states in the North Central Nigeria indicates no significant variation statistically. This explained by the $\mathrm{F}$ ratio $=0.041$ which is less than the critical $\mathrm{F}$ value of 3.239 as shown in table 7 below.

Table 7: ANOVA on the sources of housing finance

\begin{tabular}{lllllll}
\hline Source of Variation & SS & df & MS & F & P-value & F crit \\
\hline Between Groups & 310.6 & 3 & 103.533 & 0.041 & 0.988 & 3.239 \\
Within Groups & 40193.2 & 16 & 2512.08 & & & \\
Total & 40503.8 & 19 & & & & \\
\hline
\end{tabular}

\section{Time Taken by Respondents to Develop their Homes}

Considering that the predominant sources of housing finance in the study area is outside the formal financial institutions, evidence from respondents indicates that it took $43.5 \%$ (584) of them between 6 and 10 years to start and complete their houses.

Table 8: Time taken by respondents to develop their houses

\begin{tabular}{llll}
\hline Duration (Years) & $\mathrm{N}$ & Mean & SD \\
\hline $1-5$ & 371 & 92.75 & 12.09 \\
$6-10$ & 584 & 146.0 & 7.26 \\
$11 \&$ above & 387 & 96.75 & 14.71 \\
\hline
\end{tabular}

Table 8 above also shows that $387(28.8 \%)$ of the sampled households started and completed their houses between 11 years and above. Since housing development on incremental basis takes longer years than anticipated to complete, it becomes vulnerable to the effect of inflation and exchange rates on the cost of building material and other housing components. 


\section{Analysis of the factors affecting access to housing finance}

Table 9: Description of factors

\begin{tabular}{ll}
\hline Code & Variable Description \\
\hline INC & Income (Affordability criteria) \\
INT & High Interest rates \\
LAT & Land Title (Collateral) \\
OCS & Occupational Sector \\
PMI & Lack of available Primary Mortgage Institutions \\
DUL & Duration of Loan \\
\hline
\end{tabular}

Table 10: Mean and ranking of the factors affecting access to housing finance

\begin{tabular}{lllllllll}
\hline \multirow{2}{*}{ Factors } & Makurdi & \multicolumn{3}{c}{ Lokoja } & \multicolumn{3}{c}{ Lafia } & Minna \\
\cline { 2 - 9 } & Mean & Rank & Mean & Rank & Mean & Rank & Mean & Rank \\
\hline INC & 2.14 & 3 & 1.92 & 6 & 2.51 & 1 & 2.09 & 4 \\
INT & 2.34 & 1 & 2.27 & 4 & 2.44 & 2 & 2.62 & 1 \\
LAT & 2.29 & 2 & 2.51 & 1 & 2.34 & 4 & 2.31 & 3 \\
OCS & 2.06 & 5 & 1.86 & 5 & 1.81 & 6 & 1.76 & 6 \\
PMI & 2.13 & 4 & 2.35 & 2 & 2.42 & 3 & 2.38 & 2 \\
DUL & 1.88 & 6 & 2.19 & 3 & 1.95 & 5 & 1.86 & 5 \\
\hline
\end{tabular}

The rankings of the factors affecting access to housing finance and the results across the 4 cities in the study area are shown in the Table 10 above. In Makurdi, Interest rate (INT) is ranked $1^{\text {st }}$ and DUL $6^{\text {th }}$. Lokoja ranked LAT $1^{\text {st }}$ and INC $6^{\text {th }}$. In Lafia, INC is $1^{\text {st }}$ and OCS is $6^{\text {th }}$ while Minna ranked INT $1^{\text {st }}$, PMI $2^{\text {nd }}$ and LAT $3^{\text {rd }}$ respectively.

Table 11: Kendall's coefficient of concordance W

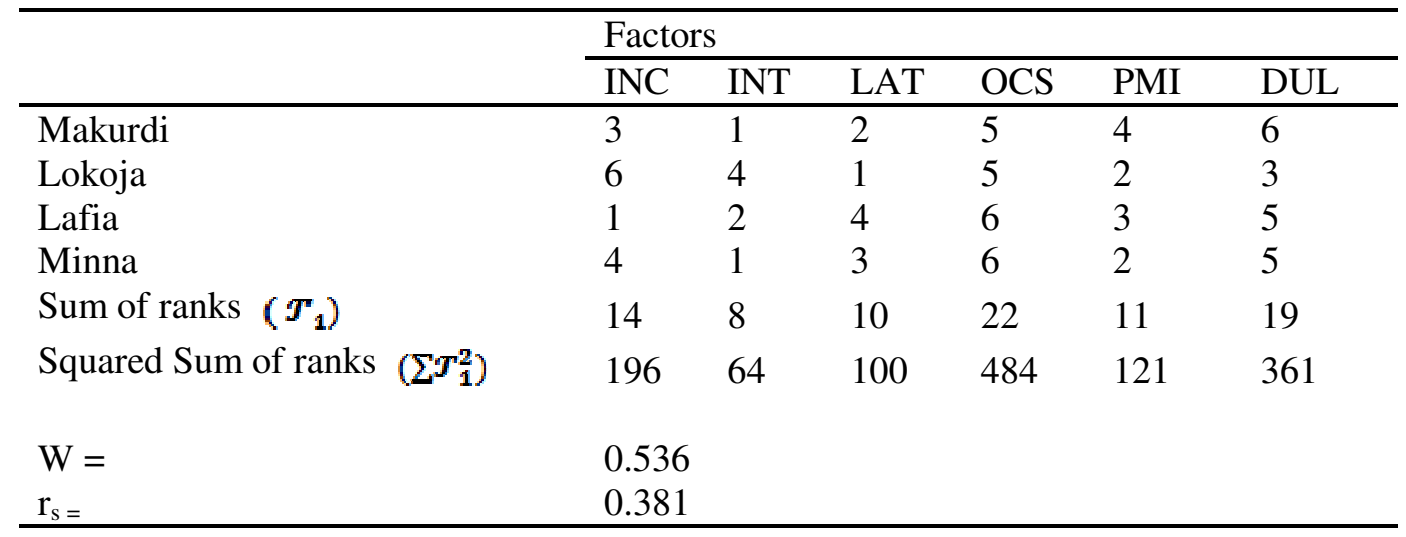

The result of the Kendall's coefficient of concordance $\mathrm{W}=0.536$ indicates a statistical evidence of a fair association in the ranking of the factors, while the average rank correlation of factors between all possible pairs of the towns $r_{s}=0.381$ indicating a weak agreement. This result thus suggests that though each state has its peculiarity in the significant effect of each factor however, the overall ranking of the factors in the study area is fairly associated. Therefore, the values from the squared sum of ranks $\Sigma T_{1}^{2}$ is extracted and used to determine the overall ranking in the study area; the figures in subscript indicate the ranking)

$\mathrm{INT}_{1} \Rightarrow \mathrm{LAT}_{\mathbf{2}} \Rightarrow \mathrm{PMI}_{3} \Rightarrow \mathrm{INC}_{4} \Rightarrow \mathrm{OCS}_{5} \Rightarrow$ DUL $_{6}$

From the overall consensus, high interest rates (INT) on loans stand as the most significant among the challenges followed by Land Titles (LAT).The absence /inadequate availability of Primary Mortgage Institutions (PMI) in the area is 
$3^{\text {rd }}$, while the other factors like income (INC), Occupational Sector (OCS) of borrowers and Duration of Loans (DUL) are ranked $4^{\text {th }}, 5^{\text {th }}$ and $6^{\text {th }}$ respectively.

Results from analysis have so far shown that income levels has limits substantially the general households' ability to access credit facilities from the formal financial institutions as shown in Table 4. Except for those within the monthly income brackets of $\$ 135,000$ (\$866.83) and above, and for a loan duration of 10 to 15 years, they will not be eligible for a loan facility of between $\$ 3.7$ million $(\$ 24,271.22$ ) and $\$ 4.2$ million $(\$ 26,968.02)$ to purchase or develop their houses. This correlates with the findings from Dung-Gwom and Mallo (2011) and Anayochukwu (2011). Besides, for those households whose income can afford them such loan amount, inadequate availability of PMIs as indicated in Table 1, will only make it very difficult for them. This is because the most available choice to prospective borrowers is DMBs (commercial banks) whose interest rates are high often reaching a prime of about $22-$ $24 \%$. These developments however, could not deter housing developments completely but rather pushed most households to resort to other sources like personal savings and borrowing from local cooperative societies to acquire or develop their homes (Table 4). Considering the fact that housing development is a capital intensive project and funding from these sources are insufficient, the most popular alternative for households is to develop on incremental basis. This took $584(43.5 \%)$ of them between 6 and 10 years and 387 (28.9\%) 11 years and above to start and complete their houses as shown in Table 8. Though results from analysis have shown inadequate availability of PMIs and households' income as critical challenges affecting access to finance, results from Kendall's coefficient indicates that interest rates and requirement of land titles as collateral are ahead of income and duration of loans. This finding is a reflection of the fact that, with the absence of PMIs in the region, borrowers are left with the option of high interest rates and cumbersome lending requirements of DMBs hence considered most challenging.

\section{Conclusion}

In view of the outcome from analysis, the study concludes that high interest rates on loans, the requirements of statutory land title as collateral and absence of PMIs are the most significant challenges affecting access to housing finance in the North Central States of Nigeria. Other factors like occupational status of borrowers and duration of loans all contributes to impede on households' access to housing finance.

\section{Recommendations}

It is hereby recommended that;

1. The Government should create a more conducive atmosphere for the establishment and operations of more PMIs and also to encourage savings through the mandatory savings scheme of the National Housing Fund (NHF).

2. The issue of land reform policies and title registration is very important and the government should facilitate same by trimming down the heavily bureaucratic procedures in land acquisition and title registration. The application of ICT tools to land administration will go a long way to facilitate this exercise.

3. The government should also lay emphasis on economic development policies that will lead to job creation and economic empowerment and also, assist the cooperative societies particularly the housing type access long term funds through the NHF. 


\section{References}

Akinmoladun, O.I. and Oluwoye, J.O. (2007). An Assessment of why the problems of Housing shortages persist in Developing Countries: A case study of Lagos Metropolis, Nigeria. Pakistan Journal of Social Sciences, 4(4): 589 - 598.

Anayochukwu, O.B. (2011). Urban Housing Financing in the SouthEastern States of Nigeria: Problems and Prospects. Journal Sustainable Development in Africa, 13(8): 268 282.

Dung-Gwom, J.Y. and Mallo, D.M. (2011). An Appraisal of the challenges of accessing credit for home acquisition by Low income earners in Nigeria. Retrieved from www.gla.ac.uk/media/media_129707 en.pdf. On 29 November, 2014.

Federal Government of Nigeria (1992). National Housing Fund Decree 79 (3) Lagos: Government Printing Press.

Kabir, I. and Ikem, M. (2013). Availability of Housing Financing Funds for private Estate Developers in Abuja, Nigeria. A paper presented at the Sustainable Building Conference 2013 organised by Coventry University, Coventry, UK.

Moss, V. (2003). Preview of Housing Finance Systems in Four Different African Countries: South Africa, Nigeria, Ghana and Tanzania. Retrieved from www.housingfinance.org/.../Africa. On 26 October, 2009.

National Bureau of Statistics (2012). Living Standard Measurement Survey.
Retrieved from www.nigerianstat.gov.ng. $\quad$ On 8 August, 2013

Ndibe, L.O. and Kuma, S.S. (2010). Bridging The Gap Created by Commercial and Mortgage Banking Institutions in Housing Delivery. In J.A.B. Olujimi, M.O. Bello, E.B. Ojo, A.O. Olotuah, M.A. Adebayo, and F.K. Omole (Eds) Man, Technological Advancement and Sustainable Environment (pp291295). Proceedings of International Conference Organized by School of Environmental Technology, Federal University of Technology, Akure, Nigeria.

Ojo, O. (2005). Borrowers' Perception of the Degree of Cumbersomeness of Lenders Requirements in Housing Finance in South-western Nigeria. Conference proceedings, The Queensland University of Technology, Brisbane, Australia, 4-8 July, 2005.

Ojo. O. and Ighalo, J.I. (2008). Factors Affecting Borrowers Choice of Housing Loan Package in Southwestern Nigeria. Housing Finance International, 23(2), 38 - 43.

Tibaijuka, A.K. (2002); "Foreword." In Financing Adequate Shelter for All. UNCHS, Nairobi.

Tomlinson, M.R. (2007). A Literature Review on Housing Finance Development in Sub-Saharan Africa. Retrieved from www.finmark.org.za on 26 May, 2009. 